complete course of treatment. There were 86 deaths among these, a percentage death-rate of 0.52 , which compares with $0 \cdot 49$ for the previous year. In addition, 1260 courses of vaccine for the prophylactic treat. ment of animals were issued during the year. The vaccine employed is a carbolized 5 per cent emulsion of sheep's brain prepared from sheep infected with the Paris fixed virus.

\section{Twenty-Five Years of Research in Dairying}

TWENTY-FIVE years ago the National Institute for Research in Dairying, University of Reading, was founded, and to celebrate the event an "Anniversary Review", compiled by the staff of the Institute, has been issued. This booklet presents a short history of the origin and development of the Institute, with a brief account of its present relationship with the farm, the dairying industry generally and the public. A summary is also given of the many and varied investigations carried out at the Institute, or in collaboration with other research centres, mainly between 1923 and the commencement of the present year.

\section{Announcements}

Prof. Richard KuhN will deliver the sixth Pedler Lecture of the Chemical Society at the London School of Hygiene and Tropical Medicine on January 27 at 5.30 p.m. The subject of the lecture will be "Synthesis of Polyenes".

THE medical faculty of the University of Zurich has elected Dr. William Cortedge of Rochester, U.S.A., an honorary doctor in recognition of his work on applied physics in medicine especially in roentgenology.

THE Rockefeller Foundation of New York has decided to award Profs. A. Kluyve of Delft and L. S. Ornstein of Utrecht financial support for five years for their radiobiological investigations, which have already been supported by the Foundation for three years.

THE Women's Medical Association of New York City offers the Mary Putnam Jacobi Fellowship (1000 dollars for one year) which is available for post-graduate work in the medical sciences. The fellowship is open to any woman graduate of an approved medical school. Further information can be obtained from Dr. Phoebe Du Bois, 150 East 73rd Street, New York.

THE Ophthalmological Society of the United Kingdom has instituted a Treacher Collins Prize of $£ 100$, which will be awarded every three years for the best essay submitted on a subject selected by the Council. It will be open to medical practitioners of any nationality, but the essay must be in English. The first subject selected is cerebro-spinal disease and its relation to the optic nerve. Essays should be submitted to the honorary secretary, 5 Racquet Court, Fleet Street, E.C.4, before December 31, 1938.

Dr. Hermann Win'sz, professor of obstetrics and gynæcology at Erlangen, has been awarded the Carlos
Heiser Medal by the International Commission of Radiologists and Roentgenologists.

AN Italian society of metaphysics has recently been founded in Rome with a presidential council consisting of Prof. Ferdinando Cazzamalli, Dr. Luigi R. Sanguineti, Prof. G. Schepia and Dr. Emilio Servado. Further information can be obtained from the secretary, Dr. L. R. Sanguineti, Via Serbelloni 2, Milan.

THE twenty-seventh Dutch Congress of Natural Science and Medicine will be held at Nymwegen on April 11-13, 1939, under the presidency of Prof. G. Holst of Eindhoven. Further information can be obtained from the general secretary, Dr. D. Coelingh, Bussum, Holland.

A LAW for the reorganization of the University of Brazil and construction of the University City at Rio de Janeiro recently passed the House of Deputies. The Federal Government is now in charge of the construction of the University City, which will include the faculties of philosophy, education, fine arts, engineering, mining and metallurgy, chemistry and pharmacy, law, politics and economy, agriculture, veterinary medicine and music. There will also be a hospital.

"Рнотоmicrography with the Vickers Projection Microscope" is the title of a booklet published by Messrs. Cooke, Troughton and Simms, Ltd., Buckingham Works, York, the present makers of the instru. ment, which was originally designed and manufactured at the Erith Works of Messrs. Vickers-Armstrong, Ltd. The apparatus is fully deseribed, together with the electrical equipment and instructions for assembly. The manner of using and maintenance are described, and chapters are devoted to the theory of the microscope and preparation of specimens. The booklet contains much information on the subject of photomicrography and the use of the microscope in steel works practice, apart from the Vickers instrument, and is fully illustrated.

Assistance in the selection of suitable scientific books for public libraries is always welcomed. We are glad to see, therefore, that Prof. B. W. Holman, who is a member of the Brentford Borough Council, has contributed to the January issue of the Fordwick - a quarterly list of books added to the Brentford and Chiswick Public Libraries-a short article on recent books on social and other non-technical aspects of science.

"T. LL. H." informs us that in his review of Sir Frederick Maurice's "Life of Lord Haldane", the date of the appointment of the Royal Commission (NATURE, Dec. 11, p. 989) should have been 1909, not 1907 .

Erratum. In the last line but one of the letter by Dr. A. S. Parkes entitled "Terminology of Sex Hormones" in NATURE of January 1, p. 36, for "thryotrophic" read "thyrotrophic". 